\title{
A novel species of thermoacidophilic archaeon, Sulfolobus yangmingensis sp. nov.
}

\author{
Ren-Long Jan, ${ }^{1}$ Jeffrey $\mathrm{Wu}^{2}{ }^{2}$ Shu-Miaw Chaw, ${ }^{3}$ Chien-Wei Tsai ${ }^{1}$ \\ and Suh-Der Tsen ${ }^{1}$
}

\begin{abstract}
Author for correspondence: Suh-Der Tsen. Tel: +8862 28267108. Fax: +886228212880. e-mail: nymutsen@ym.edu.tw
\end{abstract}

Institute of Microbiology and Immunology, National Yang-Ming University, ShihPai1, Taipei American School 2 and Institute of Botany, Academia Sinica3, Taipei, Taiwan, ROC

\begin{abstract}
A novel microbe was isolated from a geothermal vent in Yang-Ming National Park in northern Taiwan. This spherical microbe with mean cell diameter of $1.1 \pm 0.2 \mu \mathrm{m}$ is a facultatively chemolithoautotrophic archaeon that grows on elemental sulfur and reduced sulfur compounds. The optimal pH and temperature for growth are $4.0(\mathrm{pH}$ range $2 \cdot 0-6 \cdot 0)$ and $80^{\circ} \mathrm{C}$ (temperature range $65-95{ }^{\circ} \mathrm{C}$ ). Its membranes contain the lipids calditoglycerocaldarchaeol and caldarchaeol, which are common to other members of the Sulfolobaceae. Like Sulfolobus acidocaldarius, Sulfolobus shibatae and Sulfolobus solfataricus, the new isolate utilizes sugars and amino acids effectively as sole carbon sources. The G+C content of the genomic DNA was $42 \mathrm{~mol} \%$. DNA of the isolate hybridized weakly to the DNA of other Sulfolobus species. Phylogenetic analysis of the 165 rRNA indicated that the new isolate represents a deep branch within the genus Sulfolobus. On the basis of these properties, the new isolate appears to represent a new species of Sulfolobus, for which the name Sulfolobus yangmingensis sp. nov. is proposed. The type strain is strain $\mathbf{Y M 1}$.
\end{abstract}

Keywords: thermoacidophile, archaeon, Sulfolobus

\section{INTRODUCTION}

Members of the genus Sulfolobus, the first reported genus of the family Sulfolobaceae (Brock et al., 1972; Segerer et al., 1986), are characterized by aerobic growth at high temperatures and low $\mathrm{pH}$ in the presence of elemental sulfur. Members of the genus are usually found in habitats such as acidic hot springs and mud holes that contain elemental sulfur. Among the described species of Sulfolobus, Sulfolobus acidocaldarius, originally discovered in Yellowstone National Park, USA, and Sulfolobus solfataricus, originally discovered in Pisciarelli, Italy, have been used widely in research. Both species are distributed worldwide. Sulfolobus hakonensis was isolated in Hakone, Japan (Takayanagi et al., 1996).

Taiwan has many active geothermal vents. A new microbial strain was isolated from an acidic, muddy, hot spring in Longfong valley at the southern Yang-

Abbreviations: MP, maximum-parsimony; NJ, neighbour-joining.

The GenBank accession number for the 165 rDNA sequence of strain $\mathrm{YM1}^{\top}$ is $A B 010957$.
Ming National Park in northern Taiwan. The temperature of this hot spring can reach $105^{\circ} \mathrm{C}$ and the $\mathrm{pH}$ is as low as 2 . In this report, we have characterized this novel strain in terms of morphology, nutritional requirements, DNA homology with similar species and phylogenetic analysis of its $16 \mathrm{~S}$ rRNA sequence.

\section{METHODS}

Microbial strains. S. acidocaldarius DSM 639 ${ }^{\mathrm{T}}$, S. hakonensis DSM $7519^{\mathrm{T}}$, Sulfolobus shibatae DSM $5389^{\mathrm{T}}$ and $S$. solfataricus DSM $1616^{\mathrm{T}}$ were obtained from the DSMZ, Braunschweig, Germany.

Initial isolation. Muddy water was collected from a geothermal vent in Longfong valley, stored in sterile $50 \mathrm{ml}$ centrifuge tubes and brought back to the laboratory. The temperature of the gas bubbling from the vent was $105^{\circ} \mathrm{C}$. The temperature of the surrounding water ranged from 70 to $100^{\circ} \mathrm{C}$. The vent water was at $\mathrm{pH} 2 \cdot 2$ and contained the following ions and minerals (in $\mathrm{mg} \mathrm{l}^{-1}$ ): $\mathrm{Na}^{+}, 44 ; \mathrm{K}^{+}, 7 \cdot 5$; $\mathrm{Ca}^{2+}, 111 ; \mathrm{Mg}^{2+}, 34 ; \mathrm{Fe}^{2+}, 14.5 ; \mathrm{Al}^{3+}, 60 ; \mathrm{Cl}^{-}, 342 ; \mathrm{SO}_{4}^{2-}$, $1325 ; \mathrm{SiO}_{2}, 198$ (Chen, 1989). Vent water was supplemented with $0.1 \%$ yeast extract and $0 \cdot 1 \%$ glucose and then autoclaved. The $\mathrm{pH}$ was around 3.0 and was not adjusted further. A fresh sample $(0.5 \mathrm{ml})$ from the geothermal vent was inoculated into $35 \mathrm{ml}$ sterilized, supplemented vent 
water in a $125 \mathrm{ml}$ Erlenmeyer flask and incubated at $70^{\circ} \mathrm{C}$ with shaking (200 r.p.m.). As the cultures became turbid $\left(\mathrm{OD}_{520}\right.$ greater than 0.3 after about $\left.3 \mathrm{~d}\right), 0 \cdot 1 \mathrm{ml}$ culture suspension was diluted 100 -fold with sterile water. An aliquot $(0.1 \mathrm{ml})$ of the liquid was then mixed with $30 \mathrm{ml}$ modified Allen's medium containing Gelrite $(0.4 \%)$ and poured into a Petri dish in order to isolate individual colonies (Brock et al., 1972). After incubation at $70^{\circ} \mathrm{C}$ for 2 weeks, large colonies appeared both in the gel and on the surface. They were isolated and subcultured.

Microbial growth and growth media. In order to examine cell growth, the isolate was inoculated in modified Allen's medium ( $\mathrm{pH} 4 \cdot 0$ ), prepared according to Brock et al. (1972) under aerobic conditions. In order to determine the optimal temperature for cell growth, the inoculum was incubated at various temperatures from 60 to $95^{\circ} \mathrm{C}$ in $5^{\circ} \mathrm{C}$ increments. The cell density of the growing culture was measured every $4 \mathrm{~h}$ by monitoring the $\mathrm{OD}_{520}$ using a spectrophotometer (model DU 7000; Beckman). In order to examine the optimal $\mathrm{pH}$ for growth, the new isolate was inoculated in modified Allen's medium with different $\mathrm{pH}$ values ranging from 1.0 to 7.0 at 1.0 increments and then incubated at $80^{\circ} \mathrm{C}$ with shaking. The $\mathrm{pH}$ was adjusted using either $1 \mathrm{M} \mathrm{HCl}$ or $1 \mathrm{M} \mathrm{NaOH}$. The growth of cells was measured as described above.

Nutritional requirements. In order to examine the ability of the new isolate to utilize sulfur compounds, sugars and amino acids, cells growing heterotrophically on yeast extract and glucose were harvested by centrifugation (6000 r.p.m. for $15 \mathrm{~min}$ at room temperature). Cell pellets were washed twice with sterile distilled water in order to avoid carrying over residual nutrients. Cells were then cultivated in modified Allen's medium without glucose and yeast extract, but in the presence of each sugar or amino acid at a concentration of $0.1 \%$. In order to test for autotrophic growth on sulfurcontaining inorganic compounds, washed cells were placed in flasks containing modified Allen's medium without any organic compounds, but with specific sulfur compounds in suspension $(0 \cdot 1 \% \mathrm{w} / \mathrm{v})$. The flasks were streamed with compressed air containing $5 \%(\mathrm{v} / \mathrm{v}) \mathrm{CO}_{2}$ in order to provide inorganic carbon and oxygen. The growth criteria are described in legend of Table 1 . The criteria for autotrophic growth were based on both the increase in cell number and acid production.

Microscopy. Growth was observed by phase-contrast microscopy (Nikon Fluophot) with an oil-immersion objective lens and by fluorescence microscopy (Olympus BX50). For fluorescence microscopy, samples were stained with Hoechst 33258 dye (Molecular Probes) and embedded in low-meltingpoint agarose. Samples for scanning electron microscopy and negative staining were prepared by the methods of Kellenberger et al. (1958) and Kurr et al. (1991).

Determination of the DNA G + C content. DNA of the new strain was isolated according to the method of Silhavy et al. (1984). Its melting temperature was measured using the method of Marmur \& Doty (1962) with slight modifications. The following procedure was used: $50 \mu \mathrm{g}$ DNA was dissolved in the solution of $0.15 \mathrm{M} \mathrm{NaCl}$ and $0.015 \mathrm{M}$ sodium citrate ( $\mathrm{pH} 7 \cdot 0$ ). This DNA solution was then placed in a cuvette and heated from 60 to $95^{\circ} \mathrm{C}$ in increments of $2{ }^{\circ} \mathrm{C}$. At each temperature, the $A_{26 n}$ was measured using a spectrophotometer (Hitachi U-3410). The $\mathrm{G}+\mathrm{C}$ content was computed using the formula $T_{m}=69 \cdot 3+0 \cdot 41 \times(\mathrm{G}+\mathrm{C})$. For comparison and accuracy, the $T_{m}$ of DNA from Escherichia coli and $S$. hakonensis were determined by the same method to be 90 and $84.7^{\circ} \mathrm{C}$, respectively. These values are consistent with measurements reported previously.

Lipid analysis. Total lipids were extracted by the methods of Takayanagi et al. (1996). Lipids were then degraded by acid methanolysis as described by Furuya et al. (1980) and separated by TLC on silica gel plates (type HPTLC, catalogue no. 1.05631 ; Merck). The first solvent system was chloroform/methanol $(4: 1)$. After the solvent front had ascended $3 \mathrm{~cm}$, the plate was taken out and dried. The second solvent system was hexane/diethyl ether/acetic acid $(30: 20: 1)$. The plate was taken out when the front had reached the top of the plate. The spots were visualized by spraying the TLC plates with $50 \%(\mathrm{v} / \mathrm{v})$ sulfuric acid and then heating them to $150^{\circ} \mathrm{C}$ for $5 \mathrm{~min}$.

DNA-DNA hybridization. DNA was isolated according to the method of Silhavy et al. (1984), sonicated and denatured by heating in a $95^{\circ} \mathrm{C}$ dry bath. DNA was labelled with $[\alpha-$ $\left.{ }^{32} \mathrm{P}\right] \mathrm{dCTP}$ by using the Rediprime DNA labelling system (Amersham) and was then mixed with unlabelled DNA (a total of $200 \mathrm{ng}$ DNA) for use as a probe. Probes were adjusted to $1-2 \times 10^{6}$ c.p.m. $\mathrm{ml}^{-1}$ hybridization buffer. Six micrograms of single-stranded, unlabelled DNA was immobilized on nitrocellulose paper (grade BA85, pore size $0.45 \mu \mathrm{m}$, diameter $25 \mathrm{~mm}$; Schleicher \& Schuell) by using a UV cross-linker. DNA-DNA hybridization experiments were performed following the instructions described in the ExpressHyb hybridization solution user's manual (Clontech). Hybridization was performed at $68^{\circ} \mathrm{C}$ for $1 \mathrm{~h}$. Radioactivity that remained bound to the filter was then counted.

$16 S$ rRNA sequencing. In order to avoid amplifying pseudogenes (or non-functional genes) (Chaw et al., 1995), total RNA was extracted from fresh cells using the modified method of Raha et al. (1990), in which genomic DNA was removed by DNase I treatment (Boehringer Mannheim). The method of Goodman \& MacDonald (1979) was then used to synthesize first-strand cDNA with the primer R1 (5'GAGGTGATCCAGCCGCAGG-3') to prime the $3^{\prime}$ end (Takayanagi et al., 1996) and AMV reverse transcriptase (Promega). The reverse transcription reaction contained $\left(\mu l^{-1}\right)$ : 20 ng RNA template, $0.5 \mathrm{U}$ AMV reverse transcriptase, $1 \mathrm{pmol}$ primer, $5 \mathrm{nmol} \mathrm{MgCl}_{2}$ and $1 \mathrm{nmol} \mathrm{dNTPs}$. The reaction was incubated at $42^{\circ} \mathrm{C}$ for $30 \mathrm{~min}$. Three independent cDNA products were synthesized and used as templates for the PCR. PCR amplification followed the method of Chaw et al. (1995) except that primers F1 (5'TCCGGTTGATCCTGCCGGA-3'; Takayanagi et al., 1996) and R1 were used. The PCR products were purified by using the GENEIII Kit (Bio 101) and subcloned into pGEMT Easy vector (Promega). One or more clones from each of the three independent PCRs were sequenced on a PE Applied Biosystems ABI 373 DNA sequencer. The protocol and reagent kit recommended by PE Applied Biosystems were utilized. In addition to the commercial T7 and SP6 primers, which are specific to the cloning site of the vector, the following internal primers were used for sequencing: 5'GTGTCAGCCGCCGCGGTAATAC-3', 5'-GTATTACCGCGGCGGCTGACAC-3' (for reverse strand), 5'-GCGGAGAGGAGGTGCATG-3' and 5'-GACGGCCATGCACCTCTC-3' (for reverse strand). They are located at positions 515-536, 536-515, 1039-1056 and 1062-1045, respectively (based on the $16 \mathrm{~S}$ rRNA sequence of $E$. coli).

Phylogenetic analysis. To date, 14 archaeal 16S rRNA gene sequences are available in GenBank. Their accession numbers are: strain $\mathrm{YM1}^{\mathrm{T}}$, AB010957; Sulfolobus thur- 
Table 1. Utilization of sulfur compounds, sugars, amino acids and yeast extract for growth

Microbial strains were incubated at $80^{\circ} \mathrm{C}$ for 1 week. To test for autotrophic growth, compressed air with $5 \% \mathrm{CO}_{2}$ was streamed into flasks (details described in Methods). All chemicals tested were at concentrations of $0.1 \%$. The amount of growth is expressed as the ratio of the $\mathrm{OD}_{520}$ after 1 week of incubation to the $\mathrm{OD}_{520}$ before incubation (which was adjusted to $0 \cdot 05$ ), as follows: - , ratio 1 or less; \pm , ratio between 1 and 2 ; + , ratio greater than 2 (positive growth usually gave a ratio greater than 5). Data were taken from De Rosa et al. (1975) and Takayanagi et al. (1996) (S. acidocaldarius, S. solfaticus and $S$. hakonensis), Grogan et al. (1990) (S. shibatae) and Huber \& Stetter (1991) (S. metallicus and amino acid utilization data). NA, Data not available.

\begin{tabular}{|c|c|c|c|c|c|c|}
\hline Nutrient source & $\begin{array}{l}\text { Strain } \\
\text { YM1 }^{\mathrm{T}}\end{array}$ & $\begin{array}{c}\text { S. acidocaldarius } \\
\text { DSM 639 }\end{array}$ & 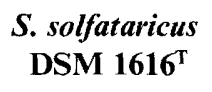 & $\begin{array}{l}\text { S. shibatae } \\
\text { DSM 5389' }\end{array}$ & $\begin{array}{c}\text { S. hakonensis } \\
\text { DSM } 7519^{\mathrm{T}}\end{array}$ & $\begin{array}{r}\text { S. metallicus } \\
\text { DSM } 6482^{T}\end{array}$ \\
\hline \multicolumn{7}{|l|}{ Sulfur compounds: } \\
\hline Elemental S & + & + & + & + & + & + \\
\hline $\mathrm{FeS}$ & + & + & + & $\mathrm{NA}$ & + & - \\
\hline Tetrathionate & + & + & + & NA & + & NA \\
\hline $\mathrm{H}_{2} \mathrm{~S}$ & NA & + & + & $\mathrm{NA}$ & + & NA \\
\hline $\mathrm{Na}_{2} \mathrm{~S}$ & - & NA & NA & $\mathrm{NA}$ & NA & NA \\
\hline \multicolumn{7}{|l|}{ Sugars: } \\
\hline D-Arabinose & + & \pm & \pm & + & - & - \\
\hline D-Ribose & \pm & - & \pm & NA & - & - \\
\hline D-Xylose & + & - & \pm & $\mathrm{NA}$ & - & - \\
\hline D-Fructose & + & \pm & \pm & $\mathrm{NA}$ & - & - \\
\hline D-Galactose & + & - & + & + & - & - \\
\hline D-Glucose & + & + & + & + & - & - \\
\hline D-Mannose & + & + & + & + & - & - \\
\hline L-Rhamnose & + & - & - & $\mathrm{NA}$ & - & NA \\
\hline Lactose & + & - & + & + & - & - \\
\hline Maltose & + & + & + & + & \pm & $\mathrm{NA}$ \\
\hline Sucrose & + & + & + & + & - & - \\
\hline Raffinose & + & + & + & + & - & - \\
\hline Sorbitol & + & NA & NA & NA & $\mathrm{NA}$ & $\mathrm{NA}$ \\
\hline Cellobiose & + & $\mathrm{NA}$ & $\mathrm{NA}$ & $\mathrm{NA}$ & NA & $\mathrm{NA}$ \\
\hline Trehalose & + & $\mathrm{NA}$ & $\mathrm{NA}$ & NA & NA & $\mathrm{NA}$ \\
\hline \multicolumn{7}{|l|}{ Amino acids:* } \\
\hline L-Aspartic acid & + & \pm & \pm & NA & - & NA \\
\hline L-Glutamic acid & + & + & \pm & NA & \pm & - \\
\hline L-Tryptophan & + & + & - & NA & \pm & NA \\
\hline Yeast extract & + & + & + & + & + & - \\
\hline
\end{tabular}

* Utilization of all 20 common amino acids by strain $\mathrm{YM1}^{\mathrm{T}}$ was tested; all were used except cysteine.

ingiensis, X90485; S. acidocaldarius, D14876; S. solfataricus, D26490; S. shibatae, M32504; Sulfolobus strain LM, U40813; Sulfolobus strain B6, U38360; S. hakonensis, D14052; Desulfurococcus mobilis, M36474; Pyrodictium occulatum, M21807; Thermofilum pedens, X14835; Thermoproteus tenax, M35966; Thermococcus celer, M21529; and Methanobacterium formicicum, M36508. We did not include the sequence of Sulfolobus metallicus (accession number $\mathrm{X} 90479$ ) in this study because there are still many undetermined sites. These sequences were aligned using the PILEUP and LINEUP programs of the Genetics Computer Group sequence analysis software.

Excluding the PCR primer positions, the length of the aligned sequences was 1445 bp (positions 40-1444), including gaps. After eliminating three regions where alignment was difficult (positions 178-198, 1111-1112 and 1390-1406), 1405 positions were available for comparison. Of these, 794 characters were constant, 227 variable characters were parsimony-uninformative and 384 were parsimony-informa- tive. The aligned sequence data (not shown) were analysed using distance and parsimony methods embodied in the software PAUP*4.0 (D. Swofford, personal communication). When using the distance method, pairwise distances were first determined by the two-parameter model of Kimura (1980). This distance matrix was then used to reconstruct a phylogenetic tree by the neighbour-joining (NJ) method (Saitou \& Nei, 1987).

The maximum-parsimony (MP) trees were derived by the heuristic search with the tree-bisection-reconnection branchswapping algorithm and MULPARs option. These searches were run on Power Macintosh 9600/233 computers. Thermococcus celer and Methanobacterium formicicum were used as outgroups as both belong to orders other than the Sulfolobales. To obtain an estimate of the strength of support for the topology of the resultant NJ and MP trees, the bootstrap method (Felsenstein, 1985) with the heuristic search was also applied to the two tree-reconstruction methods. In both trees, 1000 replicates were conducted. 


\section{RESULTS AND DISCUSSION}

\section{Growth}

Cells of strain $\mathrm{YM}^{\mathrm{T}}$ formed large colonies on the solid Gelrite surface. Since cells from a single colony were quite uniform in morphology when examined under a phase-contrast microscope, this colony appeared to be pure and was designated $\mathrm{YM}^{\mathrm{T}}$.

Although strain $\mathrm{YM}^{\mathbf{T}}$ grew slowly in autoclaved water from the geothermal vent, it grew well in modified Allen's medium supplemented with glucose and yeast extract under aerobic conditions at low $\mathrm{pH}$ and high temperature (Fig. 1). Strain $\mathrm{YM}^{\mathrm{T}}$ did not grow in the same medium when supplied with an $\mathrm{H}_{2} / \mathrm{CO}_{2}$ gas mixture. Nor did it grow anaerobically when sulfur was added to the Allen's medium. However, when elemental sulfur, FeS or tetrathionate was supplied to the Allen's medium, strain $\mathrm{YM}^{\mathrm{T}}$ grew well aerobically. Thus, strain $\mathrm{YM}^{\mathbf{T}}$ seemed to be able to grow chemolithoautotrophically by oxidizing sulfur.
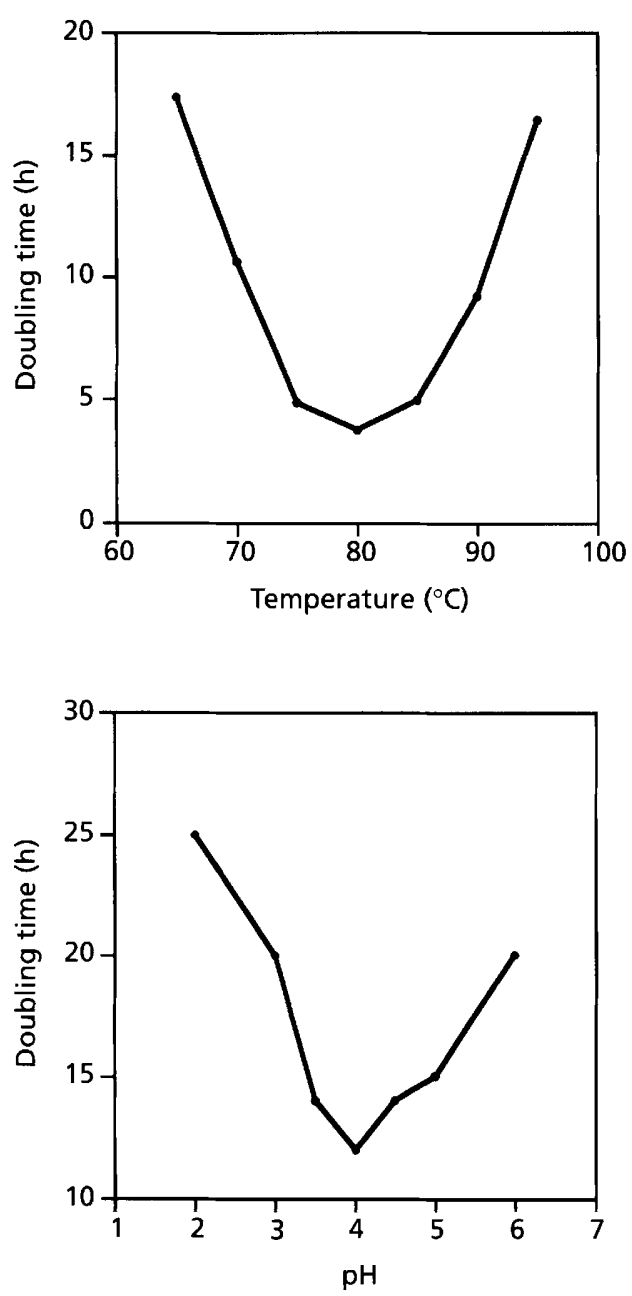

Fig. 1. The growth rate of strain $\mathrm{YM}^{\top}{ }^{\top}$ in relation to medium temperature and $\mathrm{pH}$. The optimal growth temperature is $80^{\circ} \mathrm{C}$ and optimal $\mathrm{pH}$ is 4 .

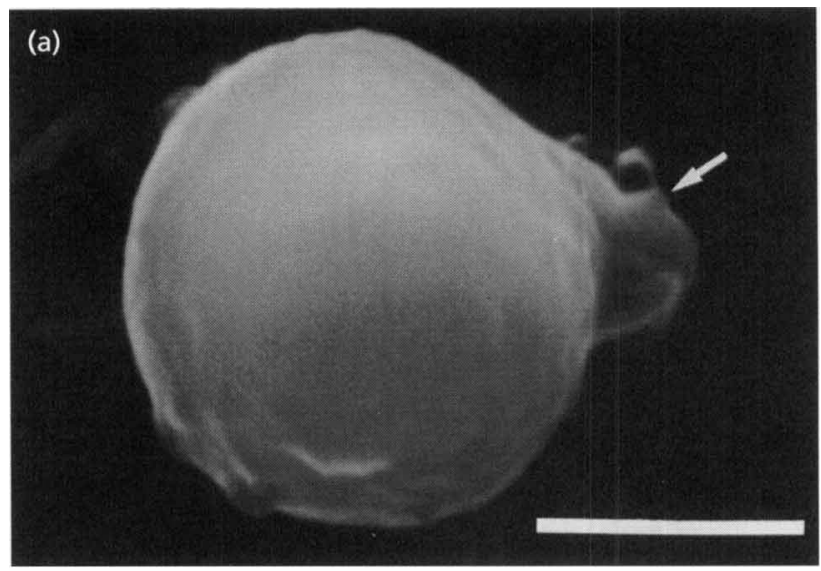

(b)

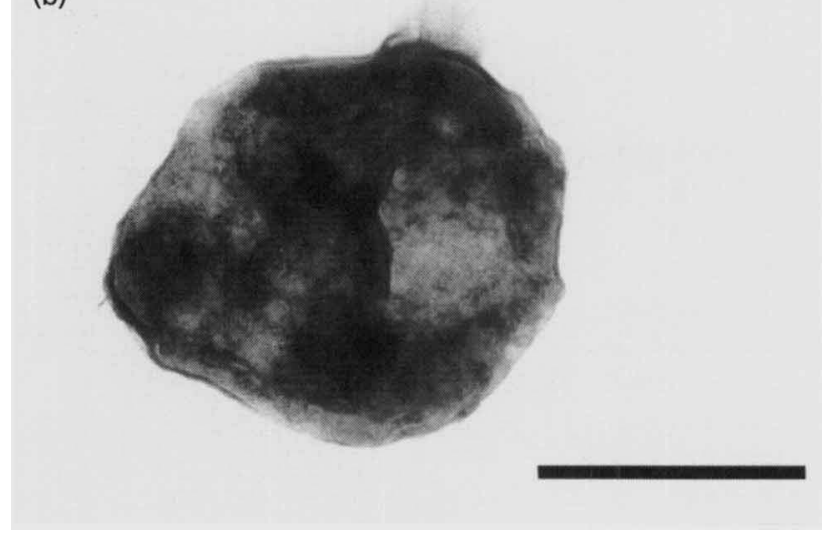

Fig. 2. Electron micrographs of strain $Y M 1^{\top}$. (a) Scanning electron micrograph of strain $\mathrm{YM1}^{\top}$. The arrowhead denotes a surface protrusion, which are often present. (b) Transmission electron micrograph of a fixed whole-mount cell negatively stained with uranyl acetate. Bars, $1 \mu \mathrm{m}$.

Strain $\mathrm{YM}^{\mathrm{T}}$ grew at temperatures from 65 to $90^{\circ} \mathrm{C}$ and at $\mathrm{pH}$ values between 2.5 and 6.0 (Fig. 1). The optimal temperature and $\mathrm{pH}$ for growth were $80^{\circ} \mathrm{C}$ and $\mathrm{pH} 4 \cdot 0$. This indicated that the new isolate was an acidophilic thermophile.

\section{Morphology}

Under the phase-contrast microscope, $\mathrm{YM}^{\mathrm{T}}$ cells did not move actively. In actively growing cell cultures, most cells had a dark cytoplasm without granules. When cells were in the stationary phase, the cytoplasm in many cells became transparent and irregularly shaped black granules appeared. While conducting an ultrastructural study of $S$. solfataricus, Millonig et al. (1975) discovered that old cultures had many dead cell ghosts with transparent cytoplasm and coagulated cytoplasmic granules. Since we observed many apparently similar cells in freshly sampled hot-spring water, we wondered whether these were dead cells. By using the DNA dye Hoechst 33258 to stain the cells, we observed that the black granules became fluorescent under UV illumination. Presumably, the black 
Table 2. Morphological, physiological and biophysical properties of strain $\mathrm{YM} 1^{\top}$ and other Sulfolobus strains

Data were taken from De Rosa et al. (1975) and Takayanagi et al. (1996) (S. acidocaldarius, S. solfaticus and $S$. hakonensis), Grogan et al. (1990) (S. shibatae) and Huber \& Stetter (1991) (S. metallicus). NA, Data not available.

\begin{tabular}{|c|c|c|c|c|c|c|}
\hline Characteristic & Strain $\mathbf{Y M 1}^{\mathrm{T}}$ & $\begin{array}{c}\text { S. acidocaldarius } \\
\text { DSM } 639^{\mathrm{T}}\end{array}$ & $\begin{array}{l}\text { S. solfataricus } \\
\text { DSM } 1616^{T}\end{array}$ & $\begin{array}{l}\text { S. shibatae } \\
\text { DSM 5389' }^{\text {TS }}\end{array}$ & $\begin{array}{l}\text { S. hakonensis } \\
\text { DSM } 7519^{T}\end{array}$ & $\begin{array}{l}\text { S. metallicus } \\
\text { DSM 6482 }\end{array}$ \\
\hline \multicolumn{7}{|l|}{ Colony morphology: } \\
\hline Colour & Dark-yellow & Dark-yellow & Greyish & Pale-tan & Dark-yellow & NA \\
\hline Shape & Smooth, flat & Smooth, flat & Smooth, flat & $\mathrm{NA}$ & Smooth, flat & $\mathrm{NA}$ \\
\hline Diameter (mm) & $1-2$ & $0 \cdot 5-1 \cdot 0$ & $0 \cdot 5-1 \cdot 0$ & NA & $0.5-1 \cdot 0$ & NA \\
\hline Cell shape & Lobed & Lobed & Lobed & NA & Lobed & Irregular \\
\hline Cell diameter $(\mu \mathrm{m})$ & $0 \cdot 8-1 \cdot 5$ & $0 \cdot 8-1 \cdot 0$ & $0.8-2 \cdot 0$ & $0 \cdot 7-1 \cdot 5$ & $0 \cdot 9-1 \cdot 1$ & 1.5 \\
\hline Flagella & - & - & - & $\mathrm{NA}$ & $\mathrm{NA}$ & NA \\
\hline Motility & - & - & - & Weak & $\mathrm{NA}$ & NA \\
\hline Cell wall & NA & + & + & + & + & + \\
\hline \multicolumn{7}{|l|}{$\begin{array}{l}\text { Temperature for } \\
\text { growth }\left({ }^{\circ} \mathrm{C}\right) \text { : }\end{array}$} \\
\hline Range & $65-90$ & $55-85$ & $55-85$ & $\mathrm{NA}$ & $50-80$ & $50-75$ \\
\hline Optimum & 80 & 70 & 70 & 81 & 70 & 65 \\
\hline \multicolumn{7}{|l|}{$\mathrm{pH}$ for growth: } \\
\hline Range & $2 \cdot 0-6 \cdot 0$ & $2 \cdot 0-4 \cdot 0$ & $2 \cdot 0-4 \cdot 0$ & NA & $1 \cdot 0-4 \cdot 0$ & $1 \cdot 0-3 \cdot 5$ \\
\hline Optimum & $4 \cdot 0$ & $2 \cdot 5$ & $4 \cdot 5$ & $3 \cdot 0$ & $3 \cdot 0$ & $\mathrm{NA}$ \\
\hline $\mathrm{G}+\mathrm{C}$ content $(\mathrm{mol} \%)$ & $42 \pm 1 \cdot 5^{*}$ & $38 \cdot 2 \pm 1 \cdot 5$ & $36 \dagger$ & $34 \cdot 6$ & $38 \cdot 4 \pm 1 \cdot 5$ & 37 \\
\hline
\end{tabular}

* Mean \pm SD from three experiments.

†Value taken from Zillig et al. (1980).

granules were condensed nucleic acids and the transparent cells were quiescent or dead cells.

Scanning electron microscope images revealed that cells of strain $\mathrm{YM}^{\mathrm{T}}$ were spherical or irregularly lobed polyhedrons with diameters of $1 \cdot 1 \pm 0 \cdot 2 \mu \mathrm{m}$ (Fig. 2). There were lobes or protrusions present on the surface. No pili, flagella or fimbriae were observed by negative staining (Fig. 2b). Such structures have not been observed in other Sulfolobus species (Millonig et al., 1975).

\section{Lipid analysis}

The membranes of thermoacidophilic archaea are monolayers based on two core lipids. Both are cyclic tetraethers, in which two polyols are linked through two $\mathrm{C}_{40}$ isoprenoid chains (De Rosa et al., 1980). The first type, caldarchaeol, has two glycerol moieties as its hydrophilic portion. The second type, calditoglycerocaldarchaeol, has glycerol and calditol as its hydrophilic portion. An analysis of the lipid core of strain $\mathrm{YM}^{\mathrm{T}}$ and four other Sulfolobus species by TLC revealed that their patterns and content were identical. Two major spots were prominent in the chromatograms of all strains. The slower-migrating spot corresponded to calditoglycerocaldarchaeol and the fastermigrating spot corresponded to caldarchaeol. Mixing lipid cores of strain $\mathrm{YM}^{\mathrm{T}}$ with those of $S$. hakonensis yielded exactly the same pattern, demonstrating the identity of their lipid cores. Since calditoglycerocald- archaeol is found only in members of the Sulfolobales (De Rosa et al., 1983; De Rosa \& Gambacorta, 1988; Lo et al., 1989), strain $\mathrm{YM}^{\mathrm{T}}$ might properly be classified in the same taxon.

The characteristics of strain $\mathrm{YM}^{\mathrm{T}}$, including its cellular morphology, its thermoacidophilic mode of life, its aerobic chemolithoautotrophic growth by utilizing sulfur and its lipid core contents, suggest that strain YM1 $1^{\mathrm{T}}$ belongs to the genus Sulfolobus.

\section{DNA analysis}

The melting temperature of DNA of strain $\mathrm{YM}^{\mathrm{T}}$ was $86.4^{\circ} \mathrm{C}$. The $\mathrm{G}+\mathrm{C}$ content of strain $\mathrm{YM}^{\mathrm{T}}$ was determined to be $42 \pm 1.5 \mathrm{~mol} \%$. This is slightly higher than the reported $\mathrm{G}+\mathrm{C}$ contents of five other Sulfolobus species (34.6-38.4 $\pm 1.5 \mathrm{~mol} \%$; Table 2$)$. However, this value is still distinct from the $\mathrm{G}+\mathrm{C}$ contents of other genera in the family Sulfolobaceae, such as those of Acidianus (30-33 mol \%) and Metallosphaera (45-47 mol\%) (Huber et al., 1989).

\section{Comparison of nutrient utilization}

Table 1 shows a comparison of utilization of different nutrients by strain $\mathrm{YM}^{\mathrm{T}}$ and the five Sulfolobus species for which data are available. Although these species resemble each other in morphology, in their affinities for hot and acidic niches and in their genomic $\mathrm{G}+\mathrm{C}$ contents, their nutritional requirements differ. 
Table 3. Percentage DNA homology as determined by DNA-DNA hybridization

Values are means $\pm S D$ from three experiments.

\begin{tabular}{|c|c|c|}
\hline \multirow[t]{2}{*}{ Source of filter-bound DNA } & \multicolumn{2}{|c|}{ Percentage of labelled probe DNA associated with filter-bound DNA } \\
\hline & Strain $\mathbf{Y M 1}^{\mathrm{T}}$ & S. hakonensis DSM $7519^{\mathrm{T}}$ \\
\hline Strain $\mathrm{YM} 1^{\mathrm{T}}$ & 100 & $6 \pm 3$ \\
\hline S. acidocaldarius DSM $639^{\mathrm{T}}$ & $16 \pm 6$ & $9 \pm 5$ \\
\hline S. solfataricus DSM $1616^{\mathrm{T}}$ & $20 \pm 5$ & $9 \pm 4$ \\
\hline S. shibatae DSM $5389^{\mathrm{T}}$ & $6 \pm 2$ & $5 \pm 2$ \\
\hline S. hakonensis DSM $7519^{\mathrm{T}}$ & $4 \pm 3$ & 100 \\
\hline E. coli & $<1$ & $<1$ \\
\hline
\end{tabular}

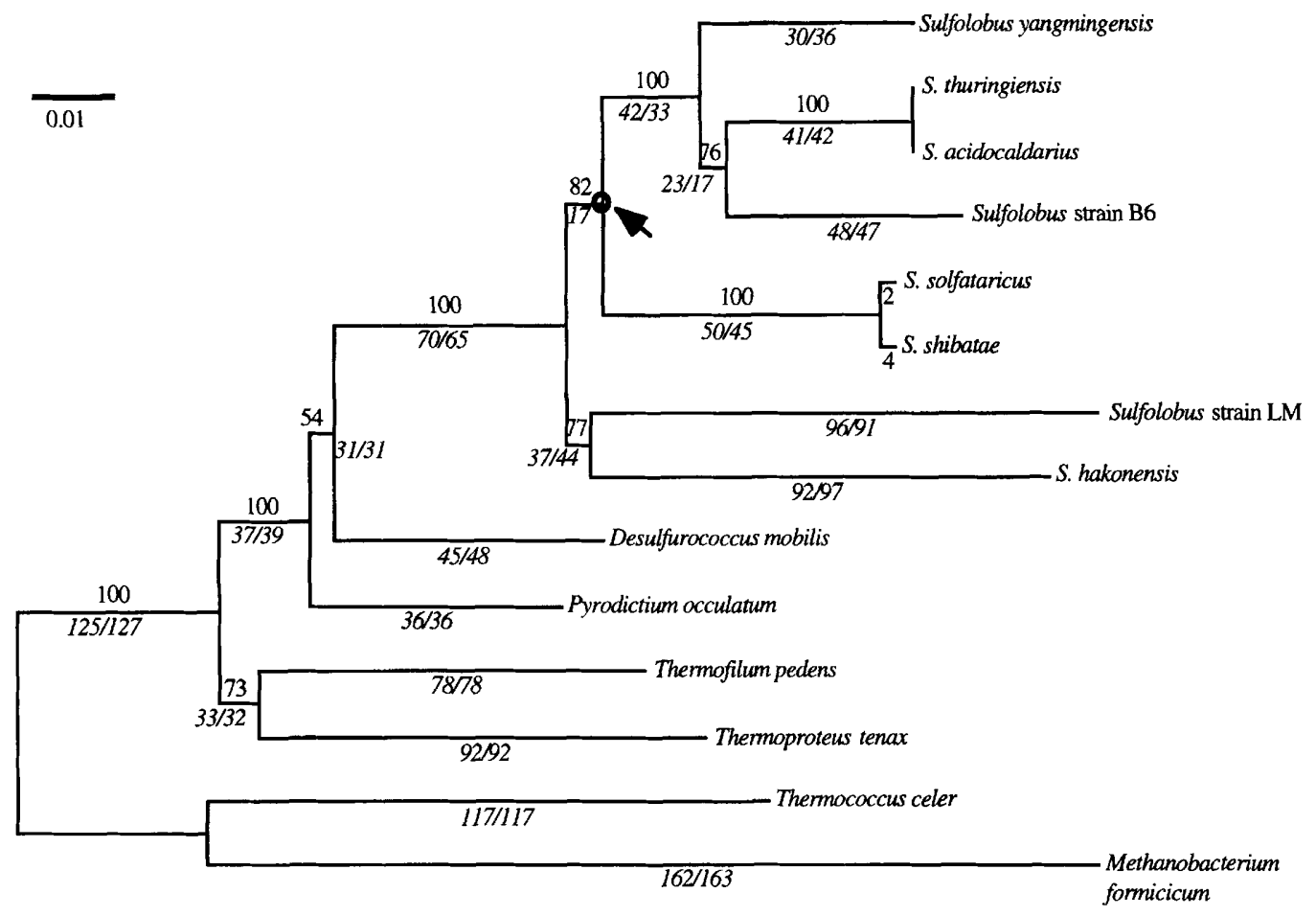

Fig. 3. Phylogenetic tree inferred from the $16 \mathrm{~S}$ rRNA sequence data. The $\mathrm{N} J$ and MP methods gave almost the same topology. The arrow indicates the node that was not present in one of the two equally most-parsimonious trees (see text for details). Branch lengths were computed by the NJ method; the bar represents one substitution per 100 nucleotides. The upper number at each node denotes the proportions of bootstrap replicates that supported the monophyly of the taxa in the subset designated by the node. The lower italicized numbers at each node refer to the number of substitutions inferred on the two equally most-parsimonious trees.

Strain $\mathrm{YM} 1^{\mathrm{T}}$ is quite versatile in using a wide range of sugars and amino acids for growth. This makes it closer to $S$. acidocaldarius and $S$. solfataricus than to $S$. hakonensis, which cannot grow on many sugars. We found that neither of the former two species, however, were able to utilize L-rhamnose, while strain $\mathrm{YM}^{\mathrm{T}}$ utilized this sugar.

Of the twenty amino acids tested, only cysteine was not utilized by strain $\mathrm{YM}^{\mathrm{T}}$. On the basis of its different abilities to utilize sulfur compounds, sugars and amino acids (Table 1), strain $\mathrm{YM}^{\mathrm{T}}{ }^{\mathrm{T}}$ is readily distinguishable from other Sulfolobus species. Furthermore, as indicated by the low hybridization rate compared with other Sulfolobus species (Table 3), strain $\mathrm{YM}^{\mathrm{T}}$ is clearly a distinct species within the genus Sulfolobus.

\section{Phylogenetic analysis}

The nucleotide sequences of 16S rRNA from 14 thermophilic archaea were compared using the LINEUP and PILEUP programs of the GCG package. A similarity matrix was then constructed by using the 
program PAUP*4.0. The 16S rRNA sequence of strain $\mathrm{YM}^{\mathrm{T}}$ was most similar to the sequences of $S$. acidocaldarius and $S$. thuringiensis and differed from them by 6.95 and $6.96 \%$, respectively. The sequences of the latter two species are exactly the same after elimination of the gaps. After these two species, the next three most similar sequences were from $S$. solfataricus, S. shibatae and Sulfolobus strain B6. Within the genus Sulfolobus, the highest divergence, which occurs between Sulfolobus strain B6 and $S$. hakonensis, was $15.46 \%$. Fig. 3 shows the phylogenetic tree inferred by the NJ and MP methods. The numbers above each node denote the bootstrap values (Felsenstein, 1985). Our heuristic search for the MP trees resulted in two equally most-parsimonious trees of 1308 substitutions or steps. One was identical to the NJ tree (Fig. 3) in its branching pattern; the other (not shown) differed from the NJ tree in the position of the clade consisting of $S$. solfataricus and $S$. shibatae. These taxa formed a sister group with the clade consisting of Sulfolobus strain LM and S. hakonensis. As can be seen from Fig. 3, there is fairly strong evidence to support the clade consisting of strain $\mathrm{YMI}^{\mathrm{T}}-S$. thuringiensis $-S$. acidocaldarius - Sulfolobus strain B6, as 42 (or 33) substitutions (numbers beneath the branch) separated these taxa from the rest of Sulfolobus.

There is even stronger evidence for the distinctness of strain $\mathrm{YM} 1^{\mathrm{T}}$, as 30 (or 36 ) substitutions separated it from the other three Sulfolobus species. Indeed, regardless of whether the phylogenetic tree was constructed by the distance or parsimony method, the genus Sulfolobus constituted a monophyletic group and strain $Y M 1^{\mathrm{T}}$ was nested within the genus and also formed a monophyletic group with Sulfolobus strain B6, S. thuringiensis and S. acidocaldarius. In addition, these monophylies were well supported by $100 \%$ of bootstrap replicates.

In conclusion, lipid analysis and $16 \mathrm{~S}$ rRNA sequencing clearly indicate that strain $\mathrm{YM} 1^{\mathrm{T}}$ is related to the described Sulfolobus taxon and should be considered as a member of the genus. Furthermore, its remarkable physiological properties, $\mathrm{G}+\mathrm{C}$ content, DNA homology and phylogenetic position distinguish it as a new species.

\section{Description of Sulfolobus yangmingensis sp. nov.}

Sulfolobus yangmingensis (yang.ming.en'sis. M.L. adj. yangmingensis pertaining to the Yang-Ming National Park, Taiwan, Republic of China, from where the organism was isolated).

Sulfolobus yangmingensis is a lobed, spherical, thermoacidophilic archaeon with a cell diameter of $1 \cdot 1 \pm 0.2 \mu \mathrm{m}$. The optimal $\mathrm{pH}$ and temperature for growth are 4.0 (range $2.0-6.0$ ) and $80^{\circ} \mathrm{C}$ (range $65-95^{\circ} \mathrm{C}$ ). It is versatile in its nutritional requirements. The $\mathrm{G}+\mathrm{C}$ content of the genomic DNA is $42 \mathrm{~mol} \%$. The major cellular lipids are calditoglycerocaldarchaeol and caldarchaeol.
The level of DNA homology and the computer analysis of 16S rRNA sequence distinguish it as a new species. The type strain of Sulfolobus yangmingensis is $\mathrm{YM}^{\mathrm{T}}$, which was isolated from an acidic, muddy hot spring.

\section{ACKNOWLEDGEMENTS}

We thank Ms Yu-Ying Yu and Ms Su-Feng Tsai of the Department of Anatomy, Yang-Ming University, for their assistance with electron microscopy. We thank $\mathrm{Dr}$ S. Takayanagi of Toho University and Dr A. Sugai of Kitasato University for help and gifts of lipids. This study was supported by a National Science Council grant, NSC872314-B-010-049, to S.-D. T. and an Academia Sinica grant to S.-M.C.

\section{REFERENCES}

Brock, T. D., Brock, K. M., Belly, R. T. \& Weiss, R. L. (1972). Sulfolobus: a new genus of sulfur-oxidizing bacteria living at low $\mathrm{pH}$ and high temperature. Arch Mikrobiol 84, 54-68.

Chaw, S. M., Sung, H. M., Long, H., Zharkikh, A. \& Li, W. H. (1995). The phylogenetic positions of the conifer genera Amentotaxus, Phyllocladus, and Nageia inferred from $18 \mathrm{~S}$ rRNA sequences. $J$ Mol Evol 41, 224-230.

Chen, J. S. (1989). Hot spring and geothermal sources in Taiwan. De-Tzu (Geology) 9, 327-340.

De Rosa, M. \& Gambacorta, A. (1988). The lipids of archaebacteria. Prog Lipid Res 27, 153-175.

De Rosa, M., Gambacorta, A. \& Bu'Lock, J. D. (1975). Extremely thermophilic acidophilic bacteria convergent with Sulfolobus acidocaldarius. J Gen Microbiol 86, 156-164.

De Rosa, M., Gambacorta, A., Nicolaus, B. \& Bu'Lock, J. D. (1980). Complex lipids of Caldariella acidophila, a thermoacidophile archaebacterium. Phytochemistry 19, 821-825.

De Rosa, M., Gambacorta, A., Nicolaus, B., Chappe, B. \& Albrecht, P. (1983). Isoprenoid ethers; backbone of complex lipids of the archaebacterium Sulfolobus solfataricus. Biochim Biophys Acta 753, 249-256.

Felsenstein, J. (1985). Confidence limits on phylogenies: an approach using the bootstrap. Evolution 39, 783-791.

Furuya, T., Nagano, T., Itoh, T. \& Kaneko, H. (1980). A thermophilic acidophilic bacterium from a hot spring. Agric Biol Chem 44, 517-521.

Goodman, H. M. \& MacDonald, R. J. (1979). Cloning of hormone genes from a mixture of cDNA molecules. Methods Enzymol 68, 75-90.

Grogan, D., Palm, P. \& Zillig, W. (1990). Isolate B12, which harbours a virus-like element, represents a new species of the archaebacterial genus Sulfolobus, Sulfolobus shibatae, sp. nov. Arch Microbiol 154, 594-599.

Huber, G. \& Stetter, K. O. (1991). Sulfolobus metallicus sp. nov., a novel strictly chemolithoautotrophic thermophilic archaeal species of metal-mobilizers. Syst Appl Microbiol 14, 372-378.

Huber, G., Spinner, C., Gambacorta, A. \& Stetter, K. O. (1989). Metallosphaera sedula gen. and sp. nov. represents a new genus of aerobic, metal-mobilizing, thermoacidophilic archaebacteria. Syst Appl Microbiol 12, 38-47.

Kellenberger, E., Ryter, A. \& Sèchand, J. (1958). Electron microscope study of DNA-containing plasma. II. Vegetative and mature phage DNA as compared with normal bacterial nucleoids in different physiological states. $J$ Biophys Biochem Cytol 4, 671-676. 
Kimura, M. (1980). A simple method for estimating evolutionary rates of base substitutions through comparative studies of nucleotide sequences. $J$ Mol Evol 16, 111-120.

Kurosawa, N. \& Itoh, Y. H. (1993). Nucleotide sequence of the 16S rRNA gene from thermoacidophilic archaea Sulfolobus acidocaldarius ATCC 33909. Nucleic Acids Res 21, 357.

Kurr, M., Huber, R., König, H., Jannasch, H. W., Fricke, H., Trincone, A., Kristjansson, J. K. \& Stetter, K. O. (1991). Methanopyrus kandleri, gen. and sp. nov., represents a novel group of hyperthermophilic methanogens, growing at $110^{\circ} \mathrm{C}$. Arch Microbiol 156, 239-247.

Lo, S. L., Montague, C. E. \& Chang, E. L. (1989). Purification of glycerol dialkyl nonitol tetraether from Sulfolobus acidocaldarius. J Lipid Res 30, 944-949.

Marmur, J. \& Doty, P. (1962). Determination of the base composition of deoxyribonucleic acid from its thermal denaturation temperature. $J$ Mol Biol 4, 109-118.

Millonig, G., De Rosa, M., Gambacorta, A. \& Bu'Lock, J. D. (1975). Ultrastructure of an extremely thermophilic acidophilic microorganism. J Gen Microbiol 86, 165-173.

Raha, S., Merante, F., Proteau, G. \& Reed, J. K. (1990). Simultaneous isolation of total cellular RNA and DNA from tissue culture cells using phenol and lithium chloride. Genet Anal Tech Appl 7, 173-177.

Saitou, N. \& Nei, M. (1987). The neighbor-joining method: a new method for reconstructing phylogenetic trees. Mol Biol Evol 4, 406-425.

Segerer, A., Neuner, A., Kristjansson, J. K. \& Stetter, K. O. (1986). Acidianus infernus gen. nov., sp. nov., and Acidianus brierleyi comb. nov. : facultatively aerobic, extremely acidophilic thermophilic sulfur-metabilizing archaebacteria. Int $J$ Syst Bacteriol 36, 559-564.

Silhavy, T. J., Berman, M. L. \& Enquist, L. W. (1984). DNA extraction from bacterial cells. In Experiments with Gene Fusions, pp. 137-139. Cold Spring Harbor, NY: Cold Spring Harbor Laboratory.

Takayanagi, S., Kawasaki, H., Sugimori, K., Yamada, T., Sugai, A., Ito, T., Yamasato, K. \& Shioda, M. (1996). Sulfolobus hakonensis sp. nov., a novel species of acidothermophilic archaeon. Int $J$ Syst Bacteriol 46, 377-382.

Zillig, W., Stetter, K. O., Wunderi, S., Schulz, W., Priess, H. \& Sholz, I. (1980). The Sulfolobus-'Caldariella' group: taxonomy on the basis of the structure of DNA-dependent RNA polymerases. Arch Microbiol 125, 259-269. 